\title{
On the Concepts and History of Glioblastoma Multiforme - Morphology, Genetics and Epigenetics
}

\section{George St. Stoyanov, Deyan L. Dzhenkov}

Department of General and Clinical Pathology, Forensic Medicine and Deontology, Prof Dr. Paraskev Stoyanov Medical University, Varna, Bulgaria

\section{Correspondence: \\ George St. Stoyanov, Department of General and Clinical Pathology, Forensic Medicine and Deontology, Prof Dr. Paraskev Stoyanov Medi- cal University, 1 Hristo Smirnenski Str., 9002 Varna, Bulgaria E-mail: georgi.geesh@gmail.com Tel: +359889922240}

Received: 17 Apr 2017

Accepted: 20 July 2017

Published Online: 23 July 2017

Published: 30 March 2018

Key words: glioblastoma multiforme, central nervous system, oncology, historical concepts review

Citation: Stoyanov GS, Dzhenkov DL. On the concepts and history of glioblastoma multiforme - morphology, genetics and epigenetics. Folia Med (Plovdiv) 2018;60(1):48-66.

doi: 10.1515/folmed-2017-0069
Glioblastoma multiforme (GBM) is a grade IV WHO malignant tumor with astrocytic differentiation. As one of the most common clinically diagnosed central nervous system (CNS) oncological entries, there have been a wide variety of historical reports of the description and evolution of ideas regarding these tumors.

The first recorded reports of gliomas were given in British scientific reports, by Berns in 1800 and in 1804 by Abernety, with the first comprehensive histomorphological description being given in 1865 by Rudolf Virchow. In 1926 Percival Bailey and Harvey Cushing gave the base for the modern classification of gliomas. Between 1934 and 1941 the most prolific researcher in glioma research was HansJoachim Scherer, who postulated some of the clinico-morphological aspects of GBM. With the introduction of molecular and genetic tests the true multifomity of GBM has been established, with different genotypes bearing the same histomorphological and IHC picture, as well as some of the aspects of gliomagenesis. For a GBM to develop, a specific trigger mutation needs to occur in a GBM stem cell - primary GBM, or a slow aggregation of individual mutations, without a distinct trigger mutation - secondary GBM.

Knowledge of GBM has been closely related to general medical knowledge of the CNS since these malignancies were first described more than 200 years ago. Several great leaps have been made in that time, in the footsteps of both CNS and advancements in general medical knowledge.

\section{INTRODUCTION}

Glioblastoma Multiforme (GBM) is a grade IV World Health Organization (WHO) malignant glial tumor with astrocytic differentiation, one of the most common intracranial oncological entries and is widely considered to be the most malignant primary intracranial tumor (Fig. 1). ${ }^{1,2}$ As one of the most common clinically diagnosed central nervous system (CNS) oncological entries, there have been a wide variety of historical reports of the description and evolution of ideas regarding these tumors ranging from purely morphological to genetic, with emphasis on both population based finding and personalized medicine. ${ }^{3-8}$

The evolution of the concepts of origin of GBM and other glial tumors has been closely related to the general knowledge and understanding of the functionality of the CNS, as well as general medical knowledge. Discovering the cells of origin of these tumors, their physiological functions and the general evolution of the tumors has been closely related to fundamental discoveries in the field of neuroanatomy, neuropathology, oncology and cell biology.

\section{GROSS MORPHOLOGY ERA}

The first recorded reports of primary, non-metastatic, CNS tumors were described in British scientific reports, only on a gross morphological level in autopsy material, by Berns in 1800 and in 1804 by Abernety as diffuse tumors formation in the CNS, which do not show a clear border with healthy tissue and are distinctly different from it. At that time the term Medullary Sarcoma was used in British literature, while Encephaloide was later coined in the French and Fungus Medullare in the German 


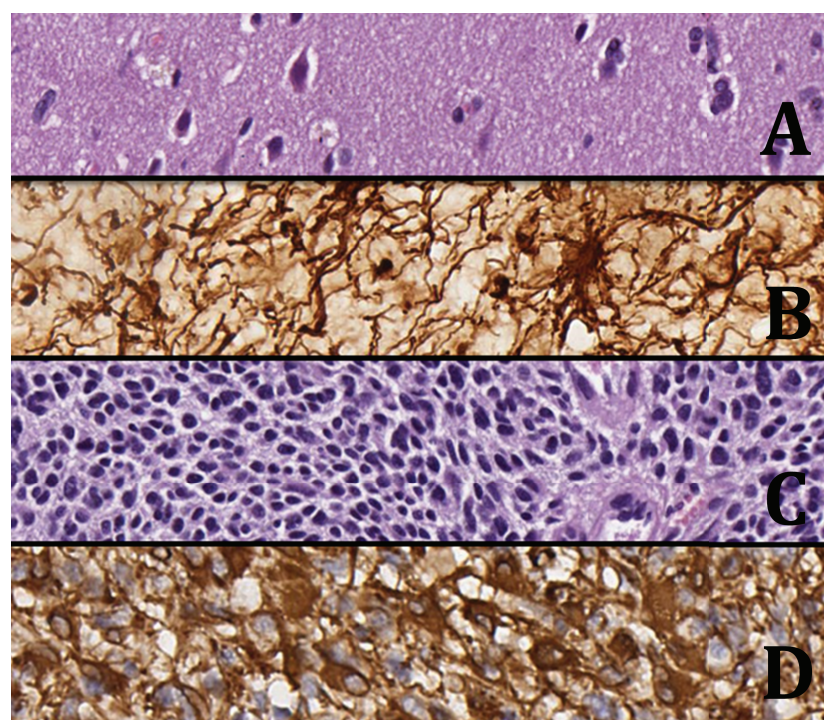

Figure 1. Cellular contrast between healthy brain tissue and GBM. A - Healthy brain tissue, H\&E, original magnification x200. B - Healthy astrocytes, IHC stain with GFAP, original magnification $\times 400$. C - Hypercellularity and cellular atypism of GBM, H\&E, original magnification $\times 400$. D - Neoplastic astrocytes of GBM, IHC stain with GFAP, original magnification $\mathrm{x} 400$.

speaking regions of the world. ${ }^{3}$ These reports were, however, based only on gross morphological observation of these tumor formations, as light microscopy had not yet been incorporated into the pathological investigation practices.

\section{HISTOLOGICAL ERA}

The first comprehensive histomorphological description of glial tumors was given in 1865 by the German pathologist Rudolf Virchow (1821-1902) as malignant tumor formations originating from the glial cells of the CNS, showing clear tissue and cellular structural contrast with healthy brain tissue and invading neighboring structures. ${ }^{6}$ Virchow was also the first to coin the term glioma for such lesions. Due to the severity of the contrast between some of the tumors on a histological level, Virchow segregated gliomas into two groups according to their cellularity and general contrast when compared to normal brain tissue. ${ }^{6}$ These two distinct groups of gliomas correspond to low grade gliomas (grades I and II) and high-grade gliomas (grades III and IV) when compared to the 2016 WHO classification of CNS tumors. ${ }^{1}$

CNS PARADIGM SHIFT AND CELLULAR CONCEPTS

These descriptions came nearly a decade after the glial cells, still viewed as a homogenous cellular population, were themselves described by Virchow during a lecture held on the April 3, 1858. The term glia, from the Greek word for glue was coined as these cells were viewed as the extracellular matrix producing cells of the CNS - neurocement. 6,9

The discovery and description of CNS glial cells and tumors originating from them turned out to be an integral part of the nervous system paradigm shift spanning the whole length of the $19^{\text {th }}$ century. ${ }^{10}$ Other key moments of this paradigm shift are marked by the discovery and description of the first neurons in 1837 by the Czech anatomist and physiologist Jan Purkinje (1787-1869) in the cortex of the cerebellum - the trivially named Purkinje cells and the special silver stains developed by Camilo Golgi (1843-1926) in 1873 and Santiago Ramon y Cajal in 1887 (1852-1934). ${ }^{11,12}$ All these discoveries were later used as the foundation for the neuronal doctrine and as counterargument to the now obsolete reticular theory regarding the structure and functionality of the CNS. ${ }^{11}$ During the latter half of the $19^{\text {th }}$ and first couple of decades of the $20^{\text {th }}$ century the individual fractions of glial cells were described and their functionality established. The Hungarian histologist Michael von Lenosec (1863-1937) first described astrocytes in 1893, the Spaniard Pio del Rio Hortega (18821945) described oligodendrocytes and microglial cells in 1919, while also postulating the individual functions of the distinct glial fractions into his neuroglial theory, complying and adding to the already dominant neuronal doctrine. ${ }^{13,14}$

\section{GOLDEN ERA}

In 1926, nearly 100 years after gliomas were first described and more than 50 years after the description of the precursor cells and the first proposed classification by Virchow, the American neuropathologist Percival Bailey (1892-1973) and the father of modern neurosurgery Harvey Cushing (1869-1939) gave the base for the modern classification of gliomas, on which the current 2016 WHO classification is based on. ${ }^{1,4}$

Bailey and Cushing called the most clinically malignant and histologically atypical form of glioma - Spongioblastoma Multiforme, due to the multiform appearance of cells within the same tissue samples. They firmly believed that this tumor type had a different cellular origin to other gliomas due to the atypical and polymorphic monstrous cells, which bear no resemblance to healthy glial and even other 
glioma cells. Other distinct tumors according to their classification are astrocytomas which originate from the astrocytic glia and their neoplastic cells and still bear some resemblance to them. ${ }^{4}$ With time, however, the term spongioblastoma was phased out and replaced with glioblastoma and the common origin of astrocytoma and GBM established.

Between 1934 and 1941 the most prolific researcher of gliomas was the German neuropathologist Hans-Joachim Scherer (1906-1945), who published a great number of research articles on the topic., ${ }^{3,15,16}$ Scherer postulated that the histomorphological diagnosis should be based on the whole tumor sample and not on individual tumor cells found in the material. Based on his research he reached the conclusion that GBM and astrocytoma share the same precursor cell of origin and that some astrocytoma cases can, in time, progress to $\mathrm{GBM}^{3}$ Therefore, Scherer coined the terms primary glioblastoma ( $\mathrm{pGBM}$ ) which arises de novo and secondary glioblastoma (sGBM) arising on the basis of a previously existing astrocytoma. Based on Scherer's estimates pGBM and sGBM share the same histomorphological hallmarks, but are widely diverse in their biological properties. The two types of GBM did not only differ in their evolution, but also in their clinical manifestation and progression - while pGBM is extremely aggressive and has a dramatic clinical course, sGBM has slower progression and a better general prognosis for the patient. ${ }^{1,3}$

Scherer also heavily researched the neovascular proliferation in GBM samples, which in some cases can even mimic the kidney glomeruli - glomerolisation phenomenon (Fig. 2) and the pseudopalisadic necrosis found commonly and considered pathognomonic for GBM. The latter term is also often referred to as geographical necrosis and Scherer formation (Fig. 3) in honor of his contributions in the field of glioma research.
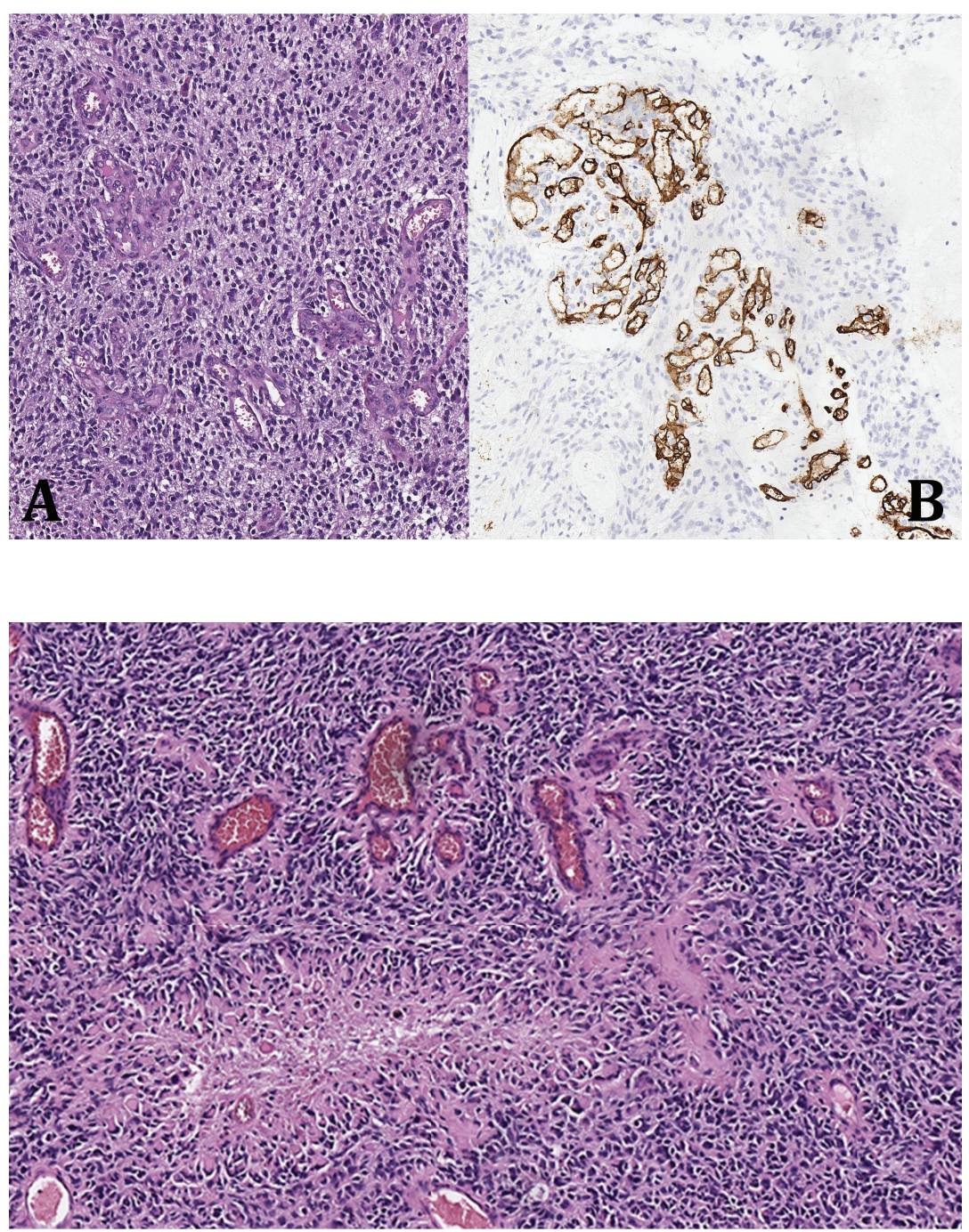

Figure 2. Neovascular proliferation in GBM. A - Immature tumor blood vessels, $\mathrm{H} \& \mathrm{E}$, original magnification $\mathrm{x} 200$. B - Endothelium of the immature tumor blood vessels, IHC stain with CD34, original magnification $\mathrm{x} 200$.

Figure 3. Tumor pseudopalisadic geographical necrosis - Scherer formation, $\mathrm{H} \& \mathrm{E}$, original magnification $\mathrm{x} 200$. 


\section{PHENO- AND GENOTYPISATION}

During the second half of the $20^{\text {th }}$ century, research in the field of cerebral gliomas took a step back, despite the introduction of new methods of morphological and non-morphological examinations. The term multiforme was also phased out and the most malignant primary brain tumor was referred to as glioblastoma for a long period of time. The biggest innovations in the field for this period were the commercial introduction of immunohistochemical (IHC) markers such as GFAP, S100, Vimentin and others which give a constant positive reaction and often help with the differential diagnosis of GBM and CNS metastatic diseases, while others give a varying IHC reaction. ${ }^{17,18}$

With the introduction of modern molecular pathological and genetic test in oncopathology practices, however, the term multiforme has once again been popularized in the last fifteen years of glioma research due to the multifomity of different genotypes bearing the same histomorphological and IHC picture. ${ }^{17-21}$

As part of the research in this area and its relevance to therapeutic approaches, based on the presence of mutations, correlating with their biological potential and not the histomorphological and IHC hallmarks, some key mutations have been identified in both pGBM and sGBM, giving a modern explanation to Scherers observations and estimations. ${ }^{1,3,6}$ The common presence of some mutations in different combinations has led to the discovery of a clinical correlation and even new therapeutic approaches to the diagnosis and treatment of GBM. ${ }^{1,22,23}$

Some mutations, such as the suppression of MGMT, have no effect on the clinical manifestation, but are extremely important in the therapeutic strategies. When the MGMT levels in the GBM cells are decreased, the cells are more susceptive to DNA alkalization, by some alkalizing agents such as temozolomide and therefore bear a better clinical and therapeutic prognosis. ${ }^{22,23}$ Temozolomide, taken orally, actively alkylates the guanin portions of DNA at the N-7 and O-6 portions, which in turn in the absence of the dealkylating effect of MGMT promotes cell death, increasing post-operative median survival to more than 13 months in case controlled studies, independent of higher dosage.

\section{MODERN CONCEPTS}

The age of molecular pathology GBM has truly revealed its multiformity, not only on the morphologic and phenotypic but also on the genotypic side, as it shows a wide variety of interlinked and independent mutations. For molecular pathology, GBM represents a heterogeneous malignant group with multiple distinct genetic and epigenetic alterations associated with a distinct clinical course. ${ }^{19}$

The differences between the two ways of occurrence of GBM are most profoundly understood at the level of genotype and epigenetic alterations. Certain mutations occur predominantly in pGBM or sGBM, however, still no single mutation has been found to be characteristic of or triggering only one forms of GBM. ${ }^{24}$

\section{CANCER STEM CELLS}

Currently, the most widely accepted hypothesis for the initiation, progression and even recurrence of GBM, regardless of it being pGBM or sGBM, incorporates the concept of mutation accumulation in neural stem cell, which develop into gliogenic cancer stem cells. ${ }^{25}$ This hypothesis also explains the existence of genotypical differences between the cells found in the same tumor sample and those of its recurrence, as the process is dynamic. These GBMsc can be identified by the presence of CD24, CD44, CD133 and Hes3 positivity and are highly resistant to treatment due to active mechanisms of DNA repair and self-regeneration. ${ }^{26,27}$ These cells can easily migrate out of the primary tumor bed, giving rise to recurrences. Though these GBMsc have similarities with neuronal stem cells, they exhibit only gliogenic potential in cell cultures and experimental models. ${ }^{26}$

The GBMsc concept explains the presence of genotypically different clonal populations of cells in the same tumor. ${ }^{26,28}$ It also explains relapses even at $100 \%$ eradication of the primary tumor. ${ }^{25}$ Some studies have shown that both GBMsc can not only initiate tumor cell lines, but these tumor cell lines possess the ability to revert back to GBMsc. This concept opens new therapeutic doors, but also presents new challenges due to the different treatment approach, as GBMsc have been shown to be quite resistant to treatment and able to migrate, grouped together with the mutual convertibility of both cell types. ${ }^{26,28}$

Due to the process of accumulation of mutations in GBMsc, mature GBM cell lines have been known to have a great variety of mutations, the most common and explicit role in oncogenesis processes. 


\section{EGFR ASSOCIATED MUTATIONS}

The gene encoding epidermal growth factor receptor (EGFR) is located on the seventh chromosome at locus 7 p12. ${ }^{29}$ Several mutant variants are encountered, resulting in over stimulation of the cell by activation of the cellular stimulation of the tyrosine kinase pathway and inhibition of apoptosis leading to gliogenic potential. ${ }^{19,21,30,31}$ The two major types of EGFR hyperstimulation in gliomagenesis are ligand-dependent and ligand-independent.

Ligand-dependent pathways are mediated primarily by receptor amplification, expression of mutant receptors that react more strongly and sustainably to normal stimuli, ligand overexpression (autocrine stimulation), or a combination of these. ${ }^{19,32}$ The ligand-dependent pathway is more common (more than $50 \%$ of all GBM) and is the result of deletion of 267 amino acids from the extracellular ligand binding domain of the receptor. ${ }^{31}$ The resulting mutant EGFRvIII receptor is constantly active regardless of the presence or absence of a ligand. ${ }^{30}$ Regardless of their type, mutations in EGFR occur and are characteristic of almost all pGBM and in much less (about 5\%) for sGBM. ${ }^{19}$ However, unlike other tumors expressing EGFR mutations, anti-EGFR drugs have no effect on tumor progression and patient survival. ${ }^{33,34}$

\section{PDGFR ASSOCIATED MUTATIONS}

Platelet derive growth factor (PDGF) has two major forms of platelet derived growth factor receptor (PDGFR) - PDGFRA and PDGFRB, with PDGFRA being of greater importance in the processes of gliomagenesis. ${ }^{19,21,31}$ The PDGFRA coding gene is located on the fourth chromosome in locus $4 \mathrm{q} 12$, this PDGFRB encoding the fifth chromosome at locus $5 \mathrm{q} 33.1 .^{35}$

The PDGFR activating ligands are PDGF-A, PDGF-B, PDGF-C and PDGF-D, with mutated combinations associated with PDGFRa PDGF-A amplifications performing auto- and paracrine overstimulation of cells and activation on a tyrosine kinase pathway like the EGFR-associated mutations. ${ }^{19,31}$ This pathway of autocrine stimulation is common in glial tumors of all classes, and may be considered an early and fundamental phenomenon in the process of gliomagenesis. ${ }^{36,37}$

In animal models' overstimulation with PDGFR$A$ in the subventricular zone (a mitotically active region of the CNS) cause the development of PDGFRa stem cells, which subsequently develop into GBM-like lesions. ${ }^{38}$ This suggests that a por- tion of stem cells in the CNS of adult individuals through over-stimulation can be transformed into GBMsc, which initiates cell lines with glioma potential. The mutations in PDGF and its ligands are predominantly characteristic of pGBM. ${ }^{19}$

\section{RAS AND NF1 ASSOCIATED MUTATIONS}

The Ras superfamily are a group of guanosine-bound protein (G-protein) involved in the signal transduction process of cellular stimuli for proliferation and blocking apoptosis. ${ }^{39}$ Ras is a complex relay station for the pathways of cellular stimulation and its activation by a tyrosine kinase mechanism leads to activation of other intracellular pathways, including the PI3K pathway. ${ }^{19,31,34}$

The main role in the processes of gliomagenesis from this group is attributed to HRAS. ${ }^{19,40,41}$ The HRAS coding gene is located at the eleventh chromosome at locus $11 \mathrm{p} 15.5 .^{42}$ Its over-activation is observed in almost all GBM, but this is extremely rare due to mutations in the coding gene.

The exogenous stimuli that activate the Ras pathway in oncogenesis of GBM are not yet fully understood, but EGFR and PDGFa are thought to play a role in tyrosine kinase stimulation. ${ }^{31}$

Neurofibromin 1 has a proven endogenous inhibitory effect on Ras. ${ }^{21,40,41}$ Neurofibromin 1 is encoded by the NF1 gene located on the seventeenth chromosome at locus $17 \mathrm{q} 11.2 .^{43}$ A mutation in NF1 resulting in loss of function and subsequent overactivation of the Ras cycle has been observed in type 1 neurofibromatosis, a syndrome known as von Recklinghausen disease, in which both peripheral nervous system tumors and almost all variants of glioma in the CNS. ${ }^{40,41,44-46}$

The MET gene has an endogenous stimulating effect on the Ras superfamily and as such is often amplified in GBM. This gene plays an important role in the PI3K pathway and processes of tumor angiogenesis. ${ }^{34,47}$

\section{RB1 AND CDK ASSOCIATED MUTATIONS}

The RB1 gene is located on the thirteenth chromosome at locus 13q14.2 and encodes the phosphoprotein $\mathrm{pRB}$, which is the key molecule in the $\mathrm{RB}$ cycle of cell proliferation suppression/activation, depending on the state of $\mathrm{pRB}$ - hypophosphorylated (active) or phosphorylated (inactive). 19,48 The active form prevents cell proliferation, while the inactive allows for its course.

In the presence of activated $\mathrm{pRB}$, transcription of genes important for mitosis is prevented and the 
cell remains blocked in the G1 phase of mitosis. In the presence of an external stimulus of growth factor, $\mathrm{pRB}$ is phosphorylated and inactivated by the formation of an active CDK4/6-cyclin D1 complex by degradation of its $\mathrm{p} 27^{\mathrm{Kip} 1}$ inhibitor by the CDK2-cyclin E complex. ${ }^{19,32}$ This allows the cell to transition from the G1 to $\mathrm{S}$ phase of the cell cycle and subsequently through the G2 and M phases through which the $\mathrm{pRB}$ is also maintained in an inactive state. Amplifications of CDK4/CDK6 and cyclin-D encoding genes are also often observed independent of RB mutations.

Proteins with the property of maintaining $\mathrm{pRB}$ in the active state by competition with cyclins for CDK are Ink4 family proteins that also form CDK complexes. P16 and its CDKN2A-p16 $16^{\mathrm{INK} 4 \mathrm{a}}$ complex, p15 and its CDKN2B-p15 INK4b complex, p18 and CDKN2C-p18 $18^{\text {INK4c }}$ complex and p19 with their CDKN2D-p19 ${ }^{\text {INK4d }}$ complex, each inhibiting the phosphorylation of $\mathrm{pRB}$ and maintaining it in the active state. ${ }^{19,36}$

Mutations in RB associated with loss of function or mutations in cyclin-dependent kinase-cyclin complexes by overproduction of enzymes or cofactors result in over-phosphorylation of $\mathrm{pRB}$ and result in sustained stimulation for cell proliferation. ${ }^{19}$ Other mechanisms associated with sustained inactivation of the RB cycle are related to the loss of the endogenous cyclin antagonists of the Ink4 family. ${ }^{19,36}$

An especially important role is played by the CDKN2A gene located on the ninth chromosome in locus 9p21 encoding both CDKN2A-p16 $6^{\text {INK4a }}$ (p16) and CDKN2A-p14 ARF (p14ARF) by alternative splicing. ${ }^{19,32,36,49}$ This gene is key and common for $\mathrm{RB}$ and p53 pathways, as its products are common activators for both pathways. ${ }^{41,50,51}$

Mutations associated with the RB pathway are more common in pGBM, with the most frequent mutation associated with loss of function in CDKN2A-p16 ${ }^{\text {INK4a }}$ (p16) or homozygous deletion of the coding genes found in more than half of the cases, followed by homozygous deletion of RB gene in about $10 \%$ of primary and more than one third of sGBM. ${ }^{19}$

\section{BRAF ASSOCIATED MUTATIONS}

The BRAF gene is encoded on the seventh chromosome at locus $7 \mathrm{q} 34$ and encodes the protein of the same name, which is a serine-threonine kinase that is actively involved in signal transduction in the cytoplasm. ${ }^{35}$ Upon activation of BRAF, by the tyrosine kinase pathway from the ligand-dependent EGFR/PDGFR systems, it actively phosphorylates the threonine regions of MAPK. ${ }^{34,40}$ MAPK is a group of kinases that further transmit the cell proliferation signal by a mechanism similar to that of CDK-cyclin complexes. The BRAF chain is susceptible to NF1 repression similar to the RB loop, which further underlines the importance of NF1 in oncogenesis processes. ${ }^{41,52}$

BRAF mutations associated with constant MAPK pathway activity are most common in pilocytic astrocytomas and, rarer in other glial tumors with higher differentiation. ${ }^{52}$ The presence of such mutations in GBM is a sure sign of secondary progression from lower-grade glial tumors. ${ }^{52,53}$

\section{PI3K AND PTEN ASSOCIATED MUTATIONS}

PI3K are a group of cytoplasmic enzymes of which the PIK3CA, encoded by a gene located on the third chromosome in locus 3q26.3 and PIK3R1, encoded by a fifth chromosome gene at locus $5 \mathrm{q} 13.1$ are of highest significance to glial tumors. ${ }^{54,55}$ These proteins are subject to activation by ligand-dependent systems located on the surface of the plasma membrane, as the EGFR/PDGFR systems and as a result of their activation activate the AKT pathway of cell stimulation and blockade apoptosis. ${ }^{56}$ Because of these properties, PI3K associated mutations, most commonly gene amplifications, play an important role in gliomagenesis.

The PI3K system is subject to stimulation and activation by the MET oncogene encoded by a gene located on the seventh chromosome at locus $7 \mathrm{q} 31 .{ }^{54}$ MET amplifications are often observed to stimulate PI3K and Ras pathways and stimulate tumor angiogenesis. ${ }^{47}$

The tumor-suppressor factor for P13K is PTEN, encoded by a gene located on the tenth chromosome at locus $10 \mathrm{q} 23.3 .{ }^{57}$ The single loss of function mutations of PTEN is extremely rare in GBM (less than 2\%). ${ }^{56,58,59}$ However, the PTEN gene plays an important role in the GBM oncogenesis, giving its position on the long arm of the tenth chromosome $(10 \mathrm{q}$ Loss of $10 \mathrm{q}$ or the whole tenth chromosome leaves the cell with only one copy of PTEN, and even at normal levels of P13K, it leads to oncogenic stimulation. ${ }^{20}$ Loss of homozygosity with respect to the $10 \mathrm{q}$ or the entire tenth chromosome is a mark found in almost all GBMs. ${ }^{32}$ This highlights the importance of P13K-PTEN in the processes of gliomagenesis. 


\section{P53 ASSOCIATED MUTATIONS}

P53 is a tumor suppressor protein encoded on the seventeenth chromosome at locus $17 \mathrm{p} 13.1$ and is involved in the cell cycle regulation, proliferation and death through a complex network of interactions tracking and regulating the DNA replication processes. ${ }^{60,61}$ In case of cellular damage, p53 activates a cascade of reactions involving epigenetic control of target genes and direct modulation of other proteins by binding to them. ${ }^{51}$ P53 alterations have a direct role in survival and maturation of GBMsc.

One of the proteins subjected to positive epigenetic control by $\mathrm{p} 53$ is $\mathrm{p} 21$, encoded by the CDKN1A gene located on the sixth chromosome in locus $6 \mathrm{p} 21.2$, the product of which blocks the cell cycle in phase G1 by binding and inactivating the cyclin-D proteins. ${ }^{50,61,62}$

Another gene undergoing positive epigenetic control by p53 in the presence of DNA damage is MDM2 localized on the twelfth chromosome at locus 12q14.3-15. MDM2 is an antagonist and inactivates p53, but only in the G1 phase of the mitotic cycle. MDM2 is bound to CDKN2A$\mathrm{p} 14^{\mathrm{ARF}}$, thereby resulting in its inactivation. By this mechanism CDKN2A-p14 ${ }^{\mathrm{ARF}}$ in turn leads to the activation of p53. ${ }^{19,63-65}$ Through this cascade, the two genes carry out a mutual regulatory process through a negative feedback. In GBM amplifications of MDM2 are often observed, inducing p53 inactivation. ${ }^{64,65}$

MDM4/MDMX is encoded by a gene located on the first chromosome at locus $1 \mathrm{q} 32$ and is with a similar function as MDM2 to p53, which also includes reciprocal feedback by binding to CDKN2A-p14ARF. Mutations in p53-MDM2 / MDM4-CDKN2A-p14 ${ }^{\mathrm{ARF}}$ (p14 ${ }^{\mathrm{ARF}}$ ) and p53-p21 cycles of cellular regulation occur at each step in GBM oncogenesis. ${ }^{54,66}$ Mutations or amplification of the p53 gene, overexpression of MDM2/MDM4 or loss of expression of CDKN2A-p14 ${ }^{\mathrm{ARF}}$ occur in various combinations with one another in over $50 \%$ of pGBM and about $70 \%$ of sGBM. ${ }^{19,66}$

\section{IDH ASSOCIATED MUTATIONS}

IDH are represented by two proteins - IDH1 encoded on the second chromosome at locus 2q33.3 and IDH2 encoded on the fifteenth chromosome at $15 \mathrm{q} 26.1$ locus. ${ }^{67-69}$ IDH1 is located in the cytoplasm of the cell and in the peroxisomes, while IDH2 is located in the mitochondria. ${ }^{70}$ Both proteins are involved in the oxidative decarboxylation of isocitrate to alpha-ketoglutarate and the reduction of NAD and
NADP to NADH and NADPH. Both enzymes play an important role in the metabolism of tricarboxylic acids and the neutralization of free oxygen radicals in the cell. As a result of mutations in the genes encoding these two proteins, the cell reduces the amount of alpha-ketoglutarate and begins to accumulate an alternative product produced by the mutant forms of the 2-hydroxyglutarate enzymes that may have potential gliomagenic effects. ${ }^{23,71}$

Mutations in IDH1/IDH2 often occur together and in combination with other mutations. They are almost exclusively characteristic of sGBM and as such are common in lower-grade gliomas. ${ }^{69}$

\section{AKT3 ASSOCIATED MUTATIONS}

AKT3 is a protein kinase encoded on the first chromosome at locus 1q44, involved in the insulin cycle of cell-stimulation and other ligand-dependent tyrosine kinase systems. ${ }^{72}$ Often GBM have an amplification in this gene, which results in constant stimulation for cell proliferation. ${ }^{73,74}$

\section{LOSS OF HETEROZYGOSITY (LOH) 10}

LOH 10 is a common feature in glial tumors. Most commonly occurring with the loss of a whole shoulder $(10 p$ or $10 q)$, but also with separate deletions in important loci play an important role. ${ }^{19,20,32,75,76}$ As already mentioned, the role of PTEN deletion in locus 10 q $23-24$ plays a major role. ${ }^{56-59}$ Single deletions in other chromosome loci, with a proven role in gliomas, are genes encoded in 10p14-15 and 10q25 loci, which are also often spotted in gliomas. Deletion in 10q25 is often associated with progression of lower-grade gliomas to sGBM. $32,75,77,78$

Various forms of $\mathrm{LOH} 10$ occur in $80 \%$ of pGBM and significantly rarer in sGBM. A $10 q$ deletion occurs in about one-third of sGBM, while $10 \mathrm{p}$ deletions are very uncommon. ${ }^{75-77,79}$

\section{LOH $22 \mathrm{q}$}

Loss of the long arm of the 22 chromosome is common in GBM. The most commonly deleted loci are the 22q12.3-13.2 and 22q13.31. ${ }^{77,80,81}$ The genes encoded in these loci have a still unclear role in gliomagenesis.

LOH $22 \mathrm{q}$ is characteristic of about half of the pGBM and more than $80 \%$ of $\mathrm{sGBM}$, with its incidence varying in lower-grade gliomas.

\section{TRISOMY 7}

A common occurrence in GBM. ${ }^{19,32}$ This phenomenon is of particular importance in gliomagneis due to the location of genes encoding EGFR, 
MET and BRAF, which have a strong oncogenic potential. $^{30,47,53}$

\section{LOH IN OTHER CHROMOSOMES}

The loss of $13 \mathrm{q}$ occurs in about $10 \%$ of pGBM and more than $30 \%$ of sGBM, most often including the locus of the RB gene. ${ }^{82,83}$

The loss of $19 q$, most commonly in $19 q 13.3$ locus, is a common occurrence in sGBM, occurring in more than half of the cases and considered to be less than $10 \%$ in pGBM $^{8,83-86}$ A similar deletion in other tumors suggests the presence of a still undetected tumor suppressor gene in this locus.

The loss of $1 p$ occurs in just over $10 \%$ of cases, both in pGBM and sGBM, most often in combination with LOH 19q. ${ }^{84-86}$ This form of codeletion is strongly associated with higher survival. ${ }^{84-86}$

Loss of $6 \mathrm{q}$ occurs in a small portion of sGBM and in about one-third of lower-grade gliomas. ${ }^{77,87}$

The loss of $9 p$ is a common occurrence with high importance due to the localization of CDKN2A in locus 9p21 and locus 9p23-24.1 where the PTPRD tumor suppressor gene is encoded. Deletions here are common in both pGBM and sGBM. ${ }^{32,82}$

Apart from classical genetic mutations, a number of epigenetic alterations have also been registered in GBM. ${ }^{25,26,88-91}$ Epigenetics can be defined as mitotic hereditary changes in gene expression that are not due to changes in the primary DNA sequence. ${ }^{92}$ Epigenetic mechanisms, including those involving DNA and histone modification to regulate gene expression, are a recognized source of phenotypic variability in biology ${ }^{93,94}$ Mechanism of epigenetic alteration, with relation to gliomagenesis, are:

\section{COMPLETE GENOMIC EPIGENETIC HYPOMETHYLATION}

It occurs in about $80 \%$ of GBM, ranging from approximately normal for healthy astrocytes to less than $50 \%$ as compared to them. ${ }^{24,25}$ This mechanism unlocks the transcription of multiple genes and is associated with rapid progression of the grade and high index of proliferative activity. ${ }^{89}$ Demethylation of the suspected oncogene MAGE-A1 is a common phenomenon amid general hypomethylization and is with a still unclear role. ${ }^{95-97}$

\section{EPigENETic activation of SaT2 and D4Z4}

It is carried out by hypomethylation, most likely occurring on the background of general hypomethylation. These are nucleotide sequences located respectively in the pericentromeric region of the 1 , 9 and 16 chromosomes and in the $4 \mathrm{q} 35$ and $10 \mathrm{q} 26$ loci, which are sites of increased fragility and strongly associated with $\mathrm{LOH} .{ }^{20,82}$ This highlights the importance of epigenetic control in GBM genesis. These phenomena are most likely to develop in parallel with prolonged nucleotide sequences in these regions and the decreased expression of DNMT3a and DNMT3b involved in DNA replication..$^{93,98}$

EPIGENETIC SUPPRESSION OF RB, PTEN, p53, p16 AND p14 It is carried out by direct hypermethylation of the genes and some of their promoters and further emphasizes their importance in the processes of tumor suppression. Their hypermethylation is another mechanism for their inactivation in gliomagenesis, an alternative to classical mutations and deletions. This type of suppression is strongly associated with sGBM. ${ }^{99,100}$

\section{EPIGENETIC SUPPRESSION OF EMP3}

EMP3 is a suggested tumor suppressor gene with a clear oncogenic role in the nervous system. In GBM similar to other tumors, the gene is deactivated by hypermethylation of its promoter. ${ }^{101}$

\section{EPIGENETIC SUPPRESSION OF PDGF-b}

It is accomplished by hypermethylation of its promoter. The result of this suppression is the nonfunctionality of the TGF- $\beta$ cycle in GBM, as it is associated with increased transcription of PDGF- $\beta .{ }^{90}$

\section{EPIGENETIC SUPPRESSION OF PCDH- $\gamma$ A11}

The protein encoded by this gene is involved in building intercellular contacts. Its epigenetic exclusion by hypermethylation has a potential role in the invasion of healthy tissues. ${ }^{102,103}$

\section{EPIGENETIC SUPPRESSION OF SOCs1}

Hypermethylation of this gene is associated with increased activity of the MAPK system. This epigenetic repression is also associated with a decrease in the radiosensitivity of GBM, which further worsens the patient's prognosis. ${ }^{104,105}$

\section{EPIGENETIC SUPPRESSION OF MGMT}

Hypermethylation of the MGMT promoter is a particularly important indicator for clinical practice. ${ }^{106}$ MGMT encodes a protein that is actively involved in the reprocessing and dealkylation of DNA in normal and oncological processes. ${ }^{22}$ In the presence of suppression of the gene, GBM are much more sensitive to alkylating agents such as temozolomide. ${ }^{22}$ This type of suppression is strongly associated with sGBM. ${ }^{107}$ 


\section{EPIGENETIC SUPPRESSION OF TIMP-3}

The TIMP-3 encoded gene belongs to the tissue inhibitors of metalloproteases. ${ }^{108}$ Its suppression is associated with a stronger ability to invade healthy tissues. This type of suppression is strongly associated with sGBM. ${ }^{108}$

\section{EPIGENETIC SUPPRESSION OF CASPASE-8}

This gene actively participates in the apoptosis cascade. ${ }^{74}$ Its hypermethylation is associated with a higher probability of relapse. ${ }^{101}$

\section{EPIGENETIC SUPPRESSION OF CITED4}

This gene encodes a transcription factor and its suppression by hypermethylation is associated with less likelihood of recurrence and a longer period between them. ${ }^{90}$

Epigenetic control in gliomagenesis is also achieved by many microRNAs (miR). ${ }^{109}$ According to their level of expression, they can be divided into three groups - with increased, decreased and dynamic levels. ${ }^{7}$

More than $260 \mathrm{miR}$ are known to have elevated GBM levels relative to healthy brain tissue. Among those with the most frequently elevated levels and role in GBM oncogenesis are

\section{INCREASED LEVELS OF MIR-10B}

Its expression is directly proportional to an increase in the anaplasticity of the process. A positive relationship between miR-10b and the urokinase receptor and Ras homologues has been established due to the HOXD10 gene, which in turn is in a feedback loop with them. ${ }^{110}$

\section{INCREASED LEVELS OF MIR-15B}

Increased levels of miR-15b are directly related to tumor progression. The gene encoding cyclin-E1 is under transcriptional control under miR-15b and its overexpression is associated with an increase in the number of cells in the G0 / G1 phase and ready to enter the $\mathrm{S}$ phase from the mitotic cycle. ${ }^{111}$

INCREASED LEVELS OF MIR-17-3P, MIR-17-5P, MIR-18A, MIR-19A, MIR-19в, MIR-20A, MIR-92A

Tagged as cluster miR-17 $\sim 92$, due to their similarity in function and expression. This group possesses oncogenic properties due to inhibition of the anti-proliferative TGF- $\beta$ RII, SMAD4 and CAMTA1 genes and positive regulation of CTGF and POLD2 playing a role in angiogenesis and DNA replication. ${ }^{7,112}$
INCREASED LEVELS OF MIR-21

At this stage, the best studied miR with a role in GBM oncogenesis. Its overexpression increases with the anaplasticity of the process. miR-21 stimulates the expression of ANP32A, SMARCA4, PTEN, SPRY2, LRRFIR1, HNRPK, TAp63 and PDCD4 and consequent increase in caspase levels, decreasing the activity of apoptosis pathways. ${ }^{113-115} \mathrm{miR}-21$ also aids the invasion of surrounding tissues by suppressing TIMP-3 and RECK, without changing the levels of matrix metalloproteases. Missense miR-21 transfection in laboratory conditions, in turn, leads to increased sensitivity to radio and chemotherapeutics. ${ }^{7}$

INCREASED LEVELS OF MIR-23A

miR-23a is directly involved in GBM proliferation, migration and invasion. miR-23a epigenetically silences APAF1, a key element of the apoptotic cascade. ${ }^{116}$

\section{INCREASED LEVELS OF MIR-93}

miR-93 participates in the suppression of integrin- $\beta 8$, which disrupts the interaction between tumor and endothelial cells and stimulation of the PI3K/AKT pathways. ${ }^{7,117}$ As a result, the expression of miR-93 is strongly associated with tumor angiogenesis and cell proliferation. ${ }^{117,118}$

\section{INCREASED LEVELS OF MIR-221 AND MIR-222}

They are associated with an increase in CDK levels by negative regulation of their inhibitors $\mathrm{p} 27^{\mathrm{Kip} 1}$ and $\mathrm{p} 57^{\mathrm{Kip} 2} \cdot{ }^{119,120}$ In this way, they are assisted in entering the $\mathrm{S}$ phase of the mitotic cycle. Their elevated levels are associated with pGBM. ${ }^{7}$

\section{INCREASED LEVELS OF MIR-335}

They are associated with an increase in the proliferative index of cells and the ability to invade healthy tissues by overexpression of DAAM1.,121

\section{INCREASED LEVELS OF MIR-381}

They are associated with an increase in the proliferative index by inhibition of LRRC4. ${ }^{121,122}$ As a result, MAPK, AKT and MEK are permanently phosphorylated and their pathways are permanently activated. ${ }^{121}$

\section{INCREASED LEVELS OF OTHER MIRS}

The role of some of the miR with increased expression in GBM has not yet been fully established. These include miR-16, which has been shown to 
play a role in several oncological conditions. miR$106 \mathrm{~b}$, which is closely associated with the levels of the miR-17-92 cluster, but with a yet undefined role. ${ }^{112}$ miR-182 and miR-183, whose role is also not yet fully specified. ${ }^{7,122}$ miR-210 which, in other oncological processes and myocardial infarction, is associated with an increase in hypoxic resistance of cells and neoangiogenesis by overexpression of HIF-1 $\alpha .{ }^{123,124}$

More than 100 miRs are known to have decreased levels in GBM, relative to healthy brain tissue. Among those with the most commonly lowered levels and role in GBM oncogenesis are:

\section{DeCREASED LEVELS OF MIR-7}

Targets are the genes encoding EGFR, IRS-2, FAK and MMPs. ${ }^{125-127}$ As a result of the decreased levels and the epigenetic enhancement of their expression, proliferative processes are stimulated and MMP-2 and MMP-9 levels are increased. ${ }^{7}$ This plays an important role in the processes of tumor migration and invasion.

\section{DeCREASED LeVEls of MIR-32}

Targets are the genes encoding MDM2 and TSC $1 .{ }^{128}$ These genes are involved in the inactivation of the p53 cycle and at reduced levels of miR-32, are involved in stimulating tumor proliferation. ${ }^{128}$

\section{DeCreased LeVELS OF MiR-34A}

Targets are genes encoding Notch1/2, MET, SIRT1, Musashi1 and PDGFRA. ${ }^{129-133}$ The rise in SIRT1 levels in the absence of its silencing by miR-34a results in persistent phosphorylation of p53 and inactivation of its cascade. ${ }^{133} \mathrm{miR}-34 \mathrm{a}$ and PDGFRA are in reciprocal feedback and possibly the amplification of PDGFRA resulting in its decreased levels in GBM. ${ }^{129}$ Increased activity of Notch $1 / 2$ and MET on this background supports the process of tumor angiogenesis, increase in the proliferation index, accumulation of new mutations, invasion of healthy tissues and suppression of apoptosis. ${ }^{131}$

\section{DeCREASEd LeVels OF MIR-101}

Targets are the genes encoding Msi1 and EZH2 encoding the enzyme portion of the PRC2 PcG protein. ${ }^{134}$ Due to decreased levels of miR-101 and stimulation of EZH2, global hypomethylation of DNA in GBM increases and assists in the activation of multiple suppressed genes, whilst the lack of suppression of Msi1 leads to increased proliferation. ${ }^{133}$

\section{DeCREASED LeVEls OF MIR-128}

Targets are the genes encoding Bmi-1, E2F3a, EGFR, PDGFRA, WEE1, Msi1 and p70SK1. ${ }^{135-137}$ Bmi-1 is a PcG protein with a known oncogene effect. E2F3A is a transcription factor and together with elevated levels of EGFR and PDGFRA stimulates cell proliferation. ${ }^{138}$ This is aided by the effects of protein kinase WEE1 involved in regulating mitotic cycles and cell size. ${ }^{139}$ Msil is an active participant in post-translational control in healthy nerve tissue, while p70S6K1 plays a role in tumor angiogenesis. ${ }^{133}$ The mutually elevated levels of these proteins at reduced levels of miR-128 cover key units in GBM oncogenesis.

\section{DeCREASED LEVELS OF MIR-132}

An epigenetic target is the gene encoding the p120RasGAP protein. ${ }^{140}$ This protein has the ability to ontogenically activate the Ras cascade. miR-132 is also associated with tumor angiogenesis and progression. ${ }^{141}$

\section{DeCReAsed LeVels of MiR-137 AND MIR-124}

These two miRs are closely related and often their levels vary in parallel. Under their control are the CDK6, Msi1 and Cox-2 coding genes. ${ }^{133,142}$ An increase in their levels with correlating decreased miR-137 and miR-124 results in enhanced tumor proliferation.

\section{DeCREASEd LeVels of MiR-326}

Under its control are the genes encoding Noch $1 / 2$ and PKM2. ${ }^{143-145}$ It is assumed that miR-326 is located in a loop with a reciprocal negative feedback connection with Notch1. Elevated levels of PKM2 in turn are related to the effect of Warburg, in which tumor cells produce ATP by glycolysis followed by cytosolic fermentation of lactic acid. ${ }^{146,147}$

\section{Decreased LeVels of MiR-483-5P}

An epigenetic target is the gene coding for ERK1 and MAPK3, a key in Ras and BRAF pathways of proliferation. Decreased levels of miR-483-5p are directly related to the increased proliferative capacity of tumor cells. ${ }^{148,149}$

\section{DeCREASED LEVELS OF MiR-491-5P}

An epigenetic target is the gene coding for MMP9. ${ }^{150}$ As a result of an increase in MMP-9 levels in a correlating decrease in miR-491-5p levels, leads to an increased invasion of healthy brain tissue. ${ }^{151}$ 
DeCREASED LEVELS OF OTHER MIRS

Often detected, but with a still unclear role in the processes of gliomagenesis are miR-139-5p, miR$181 \mathrm{~b}, \mathrm{miR}-218$ and others. ${ }^{7}$

Another group of miRs exhibits quantitative variability. Such relative and dynamic changes are encountered in some of the following miRs

\section{Dynamic Changes IN THE AMOUNT OF MIR-145}

Decreased levels of miR-145 are directly related to an increase in the amount of protein synthesized by the suppressed genes. ${ }^{152-155}$ This includes transcription factors Sox-2 and OCT4. ${ }^{152}$ An increase in their amount is associated with an increase in proliferative potential and a decrease in the chemosensitivity of GBM. Decreased levels of miR-145 in turn are associated with an increase in the invasive ability of the tumor. ${ }^{153}$

\section{DyNAMIC CHANGES IN THE AMOUNT OF OTHER MIRS}

Often, dynamic changes have been observed in miR19a, miR-26b, miR-27b, miR-106a, miR-143, miR205, and miR-451. At this stage, their importance and role in gliomagenesis are not yet specified. ${ }^{7}$

Whilst an extremely large number of genetic and epigenetic changes have been shown to play a role in the genes of GBM, the importance of only a part of them in the prognosis and treatment options has however been clarified. It is on the basis of these clinically relevant indicators that some study groups have proposed classification formulas. The aim of these classifications is to optimize the healing process and to invest in the most effective healing approach in the presence of certain mutations in tumor cell genotype.

Most well-established GBM genetic classification models are centered, around the highest rate of change, and those with the clearest role, such as mutations affecting EGFR, CDKN2A, PTEN, PI3K, p53 and NF1 coding genes, and other factors such as the age of the patient and the correlating survival in these cases.

One of the first attempts for such a classification was made by Phillips and his team in 2006. ${ }^{59}$ They distributed a total of 76 cases of GBM in three groups with proneuronal, proliferative and mesenchymal characteristics. An analysis of the results obtained shows that:

\section{Proneuronal GBM}

Found predominantly in younger individuals (average age less than 40 years) and is with the longest survival period for this study group. In the proneuronal type, genotypically no alterations appeared in the number of chromosomes and no changes were observed in the PNET and EGFR coding genes. ${ }^{59}$ According to the authors, the leading role in oncogenesis here are the dysregulated processes of neurogenesis, as a key place for the Notch pathways, key to the embryogenesis of the nervous system. ${ }^{59}$

\section{Proliferative GBM}

Found predominantly in older individuals (average age over 50 years) and with a shorter survival period. In the proliferative type, genotypically trisomy 7 and LOH 10 are detected, together with a loss of PTEN and amplifications in EGFR. ${ }^{59}$ According to the authors, the dysregulated processes of cell proliferation, crossing at the level of AKT, have a leading role in oncogenesis for this type. ${ }^{59}$

\section{Mesenchymal GBM}

Again, characteristically found in older individuals (average age over 50 years) and also has a shorter predicted survival period. The mesenchymal type, genotypically also has trisomy 7 and $\mathrm{LOH} \mathrm{10,} \mathrm{loss}$ of PTEN and frequent amplifications in EGFR. ${ }^{59}$ According to the authors, the dysregulated processes of cell proliferation also play a role here, but the processes of tumor angiogenesis are also key. ${ }^{59}$

Verhaak and his team also classified GBM based on genetic changes and patient outcome. ${ }^{21}$ The results achieved by them and the classes based on them show a similarity to the Phillips classification. $^{21,59}$ They classify a total of 170 GBM cases in four categories

\section{Proneuronal GBM}

Found predominantly in patients with an average age of 51.8 years. This group is characterized by amplification of PDGFRA and mutations in IDH and PI3K and loss or inactivation of $\mathrm{p} 53 .{ }^{21}$ The mean survival rate for this group is 11.3 months. Three quarters of all sGBM according to the authors enter this subgroup. ${ }^{21}$

\section{Neural GBM}

Found predominantly in patients with an average age of 63.8 years. Various mutations with different frequencies are characteristic of this group, among which are amplifications in EGFR, loss of PTEN and p53. ${ }^{21}$ Also, characteristic of this group is the lack of PDGFRA amplification and the EGFRvIII mutant form of EGFR. The median survival rate for this group is 13.1 months. $^{21}$ 


\section{Classic GBM}

Found predominantly in patients with an average age of 55.7 years. This group is characterized by amplifications in EGFR, including EGFRvIII mutant form, loss of PTEN/LOH10 and CDKN2A/LOH9. ${ }^{21}$ Also, characteristic of this group are the lack of mutations in p53, IDH, RB and PDGFRA. The median survival in this group was 12.2 months. ${ }^{21}$

\section{Mesenchymal GBM}

Found predominantly in patients with an average age of 57.7 years. This group is characterized by loss of NF1/LOH17, PNET and p53. ${ }^{21}$ Characteristic of the group is also a complete lack of mutations affecting IDH and lack of amplification of PDGFRA. The median survival in this group was 11.8 months. ${ }^{21}$

In 2011, Crespo and his team divided a total of 35 GBM patients into five subclasses according to frequently observed combined changes in the chromosomal set and/or specific genes with a defined role in gliomagenesis. ${ }^{32}$ According to their data, the five different classes did not show significant differences in clinically relevant parameters such as age and survival. ${ }^{32}$ The five classes and their characteristics are:

\section{GBM PATTERN I}

Characteristic of this class are amplifications in EGFR, LOH10 and deletion of the CDKN2A/ LOH9. ${ }^{32}$

\section{GBM PATTERN II}

Typical for this class are trisomy 7, loss of CD$\mathrm{KN} 2 \mathrm{~A} / \mathrm{LOH} 9$ and LOH10. ${ }^{32}$

\section{GBM PATTERN III}

Typical for this class are trisomy 7, loss of CD$\mathrm{KN} 2 \mathrm{~A} / \mathrm{LOH} 9$ or paradoxically doubling of $9 \mathrm{q}$, but lack of change relative to chromosome $10 .{ }^{32}$

\section{GBM PATTERN IV}

Typical for this class are trisomy 7 and $\mathrm{LOH} 10$, without loss of CDKN2A/LOH9. ${ }^{32}$

\section{GBM PATTERN V}

Characteristic of this class are trisomy 7 and 9 and LOH $10 .{ }^{32}$

The divisions in separate types are relative to the study, due to the approach and selection of markers, difference in the number of cases and the possible medical and non-medical population differences.
However, there is a relative similarity between the mesenchymal and the proliferating type of Phillips, the classic version of Verhaak and pattern I in Crespo. ${ }^{19,21,32,59}$ Joining factors here are, in one form or another, the loss of PTEN, amplification in EGFR and loss of CDKN2A/LOH9, although there are differences in their description.

Relative similarities can be found in the proneuronal type of Phillips and Verhaak and pattern III in Crespo, as well as between the mesenchymal type of Verhaak and pattern II in Crespo. ${ }^{19,21,32,59}$ In these comparisons, however, the differences are greater and the correlation of these classes to a common denominator is questionable at best.

A multi-level approach with a broader range of markers with proven relevance and application will most likely be required to produce a single genotypical classification and validate it in practice, allowing for a comparison of clinical indicators such as mean age and survival, risk factors, ethnicity and others.

The 2016 revised WHO classification of tumors of the CNS implemented a number of the breakthroughs in molecular pathology of glial tumors, without dwelling too deep into the wide variety of detectable mutations. ${ }^{1}$ Instead focusing only on everyday diagnostics with commercially available methods and long-established varieties, relevant to patient survival and treatment. As such, GBM were segregated into three molecular subtypes - IDH wildtype (non-mutated IDH), IDH mutants and a subset of GBM not otherwise specified (NOS), for whom IDH verification could not be carried out. ${ }^{1,156}$

\section{FUTURE DIRECTIONS}

The variety of genetic and epigenetic mutations and alterations in GBM will inevitably lead to new additions to the WHO classification, based on the study groups preposition. Novel candidates for future WHO classification addition to GBM subtypes are MGMT and miR-21 mutants, together with CD133/ Hes3 positive GBMsc percentage in tissue volume. The discovery of new mutations, oncogenes and the establishment of some factors already known to be present in GBM, but with a yet unspecified role will inevitably lead to new breakthroughs and possibly treatment modalities for these cases.

Treatment wise, combined surgical, chemo- and radiotherapy give the best patient results, whilst a large number of new modalities are currently undergoing testing and, whilst a large number of the will inevitably prove to have no effect of patient 
survival, some of them such as viral and vaccine therapy are showing prominence..$^{30,97,157-160}$

On the other hand, a number of new diagnostic methodologies may move the verification process away from classical pathology with the implementation of liquid based biopsy and serum GFAP levels proving and increasingly affordable method, albeit for the time being only for patient follow up. ${ }^{161-165}$

\section{CONCLUSION}

GBM and its related oncological entries have been closely related to the general knowledge of the CNS, medicine in general and cell biology since these malignancies were first described more than 200 years ago. ${ }^{3}$ A number of great leaps have been made in that time regarding the phenotypisation, genetic and epigenetic multiformity. ${ }^{25}$ However, despite that, the mean survival of patients with GBM has historically remained nearly unchanged. ${ }^{106,166,167}$

\section{REFERENCES}

1. Louis DN, Perry A, Reifenberger G, et al. The 2016 World Health Organization Classification of Tumors of the Central Nervous System: a summary. Acta Neuropathol 2016;131(6):803-20.

2. Ostrom QT, Gittleman H, Liao P, et al. CBTRUS statistical report: primary brain and central nervous system tumors diagnosed in the United States in 2007-2011. Neuro Oncol 2014;16(suppl 4):iv1-iv63.

3. Scherer HJ. A critical review: the pathology of cerebral gliomas. J Neurol Neurosurg Psychiatry 1940;3(2):147-77.

4. Ferguson S, Lesniak MS. Percival Bailey and the classification of brain tumors. Neurosurg Focus 2005;18(4):1-6.

5. Altaner C. Glioblastoma and stem cells - minireview. Neoplasma 2008;55(5):369-74.

6. De Angelis LM, Mellinghoff IK. Virchow 2011 or how to $\mathrm{ID}(\mathrm{H})$ human glioblastoma. J Clin Oncol 2011;29(34):4473-4.

7. Moller HG, Rasmussen AP, Andersen HH, et al. A systematic review of MicroRNA in glioblastoma multiforme: micro-modulators in the mesenchymal mode of migration and invasion. Mol Neurobiol 2013;47(1):131-44.

8. Olar A, Aldape KD. Using the molecular classification of glioblastoma to inform personalized treatment. J Pathol 2014;232(2):165-77.

9. Virchow R. Cellular pathology as based upon physiological and pathological histology; twenty lectures delivered in the Pathological Institute of Berlin during the months of February, March, and April, 1858. 1860. p. 1-546.

10. Allen NJ, Barres BA. Neuroscience: Glia - more than just brain glue. Nature 2009;457(7230):675-7.

11. Dikranian K. The amazing brain. Biomed Rev 2015;26:1-12.

12. Kettenmann H, Verkhratsky A. Neuroglia: the 150 years after. Trends Neurosci 2008;31(12):653-9.

13. Stahnisch FW, Bulloch AGM. Mihaily (Michael von) Lenhossek (1863-1937) J Neurol 2011;258(10):1901-3.

14. Gill AS, Binder DK. Wilder Penfield, Pío del RíoHortega, and the discovery of oligodendroglia. Neurosurgery 2007;60(5):940-8.

15. Peiffer J, Kleihues P. Hans-Joachim Scherer (19061945), pioneer in glioma research. Brain Pathol 1999;9(2):241-5.

16. Scherer M. Some comments on the paper: HansJoachim Scherer (1906-1945), pioneer in glioma research. Brain Pathol 2013;23(4):485-7.

17. Stoyanov GS, Dzhenkov D, Ghenev P. Cytokeratin AE1/AE3 mimicry in glioblastoma. Scr Sci Medica 2017;49(1):47-52.

18. Stoyanov GS, Dzhenkov D, Ghenev P. The great imitator - EMA positive glioblastoma multiforme. Scr Sci Medica 2017;49(1):21-5.

19. Crespo I, Vital AL, Gonzalez-Tablas M, et al. Molecular and genomic alterations in glioblastoma multiforme. Am J Pathol 2015;185(7):1820-33.

20. Kuga D, Mizoguchi M, Guan Y, et al. Prevalence of copy-number neutral LOH in glioblastomas revealed by genomewide analysis of laser-microdissected tissues. Neuro Oncol 2008;10(6):995-1003.

21. Verhaak RGWW, Hoadley KA, Purdom E, et al. Integrated genomic analysis identifies clinically relevant subtypes of glioblastoma characterized by abnormalities in PDGFRA, IDH1, EGFR, and NF1. Cancer Cell 2010;17(1):98-110.

22. Combs SE, Rieken S, Wick W, et al. Prognostic significance of IDH-1 and MGMT in patients with glioblastoma: One step forward, and one step back? Radiat Oncol 2011;6(1):115.

23. Yang $\mathrm{P}$, Zhang W, Wang Y, et al. IDH mutation and MGMT promoter methylation in glioblastoma: results of a prospective registry. Oncotarget 2015;6(38):40896.

24. Bleeker FE, Molenaar RJ, Leenstra S. Recent advances in the molecular understanding of glioblastoma. J Neurooncol 2012;108(1):11-27.

25. De Almeida Sassi F, Lunardi Brunetto A, Schwartsmann G, et al. Glioma revisited: from neurogenesis and cancer stem cells to the epigenetic regulation 
of the niche. J Oncol 2012;2012:1-20.

26. Safa AR, Saadatzadeh MR, Cohen-Gadol AA, et al. Glioblastoma stem cells (GSCs) epigenetic plasticity and interconversion between differentiated nonGSCs and GSCs. Genes Dis 2015;2(2):152-63.

27. Park DM, Jung J, Masjkur J, et al. Hes3 regulates cell number in cultures from glioblastoma multiforme with stem cell characteristics. Sci Rep 2013;3(1):1095.

28. Bao S, Wu Q, McLendon RE, et al. Glioma stem cells promote radioresistance by preferential activation of the DNA damage response. Nature 2006;444(7120):756-60.

29. EGFR Gene - GeneCards. EGFR Protein / EGFR Antibody [Internet]. Database, Gene Cards Human Gene. Available from: http://www.genecards.org/ cgi-bin/carddisp.pl?gene=EGFR

30. Szopa W, Burley TA, Kramer-Marek G, et al. Diagnostic and therapeutic biomarkers in glioblastoma: current status and future perspectives. Biomed Res Int 2017;2017:8013575.

31. Carrasco-García E, Saceda M, Martínez-Lacaci I. Role of receptor tyrosine kinases and their ligands in glioblastoma. Cells 2014;3(2):199-235.

32. Crespo I, Vital AL, Nieto AB, et al. Detailed characterization of alterations of chromosomes 7 , 9 , and 10 in glioblastomas as assessed by singlenucleotide polymorphism arrays. J Mol Diagnostics 2011;13(6):634-47.

33. Taylor TE, Furnari FB, Cavenee WK. Targeting EGFR for treatment of glioblastoma: molecular basis to overcome resistance. Curr Cancer Drug Targets 2012;12(3):197-209.

34. Padfield E, Ellis HP, Kurian KM. Current therapeutic advances targeting EGFR and EGFRvIII in glioblastoma. Front Oncol 2015;5:5.

35. PDGFRA Gene - GeneCards. PGFRA Protein / PGFRA antibody [Internet]. Available from: https:// genecards.weizmann.ac.il/v3/cgi-bin/carddisp.pl?g ene $=$ PDGFRA\&search $=5 \mathrm{bf} 20507 \mathrm{~b} 757 \mathrm{dd} 624886 \mathrm{da}$ c9baef5c7d

36. Westermark B. Platelet-derived growth factor in glioblastoma - driver or biomarker? Ups J Med Sci 2014;119(4):298-305.

37. Nazarenko I, Hede S-M, He X, et al. PDGF and PDGF receptors in glioma. Ups J Med Sci 2012;117(2):99-112.

38. Jackson EL, Garcia-Verdugo JM, Gil-Perotin S, et al. PDGFR alpha-positive B cells are neural stem cells in the adult SVZ that form glioma-like growths in response to increased PDGF signaling. Neuron 2006;51(2):187-99.

39. Rajasekhar VK, Viale A, Socci ND, et al. Oncogenic Ras and Akt signaling contribute to glioblastoma formation by differential recruit- ment of existing mRNAs to polysomes. Mol Cell 2003;12(4):889-901.

40. Ratner N, Miller SJ. A RASopathy gene commonly mutated in cancer: the neurofibromatosis type 1 tumour suppressor. Nat Rev Cancer 2015;15(5):290-301.

41. McGillicuddy LT, Fromm JA, Hollstein PE, et al. Proteasomal and genetic inactivation of the NF1 tumor suppressor in gliomagenesis. Cancer Cell 2009;16(1):44-54.

42. HRAS Gene - GeneCards. RASH Protein / RASH Antibody [Internet]. Available from: https://genecards.weizmann.ac.il/v3/cgi-bin/carddisp.pl?gen $\mathrm{e}=$ HRAS\& $\&$ arch $=\mathrm{c} 677$ aad158f8bd824bbee69d1e dd692e

43. NF1 Gene-GeneCards. NF1 Protein / NF1 Antibody [Internet]. Available from: http://www.genecards. $\mathrm{org} /$ cgi-bin/carddisp.pl?gene $=\mathrm{NF} 1$

44. McNeill KA. Epidemiology of brain tumors. Neurol Clin 2016;34(4):981-98.

45. Karajannis MA, Ferner RE. Neurofibromatosisrelated tumors. Curr Opin Pediatr 2015;27(1):26-33.

46. Rosenfeld A, Listernick R, Charrow J, et al. Neurofibromatosis type 1 and high-grade tumors of the central nervous system. Child's Nerv Syst 2010;26(5):663-7.

47. Kwak Y, Kim SI, Park CK, et al. C-MET overexpression and amplification in gliomas. Int J Clin Exp Pathol 2015;8(11):14932-8.

48. RB1 Gene - GeneCards. RB Protein / RB Antibody [Internet]. Available from: http://www.genecards. org/cgi-bin/carddisp.pl?gene $=$ RB1\&keywords $=r b 1$

49. CDKN2A Gene - GeneCards. CD2A2 Protein / CD2A2 Antibody [Internet]. Available from: https:// genecards.weizmann.ac.il/v3/cgi-bin/carddisp.pl?g ene $=$ CDKN2A\&search $=086671 \mathrm{f} 4507 \mathrm{e} 548 \mathrm{c} 21 \mathrm{ced} 3$ a1195e 1832

50. Reavey-Cantwell JF, Haroun RI, Zahurak M, et al. The prognostic value of tumor markers in patients with glioblastoma multiforme: Analysis of $32 \mathrm{pa}-$ tients and review of the literature. J Neurooncol 2001;55(3):195-204.

51. Popova SN, Bergqvist M, Dimberg A, et al. Subtyping of gliomas of various WHO grades by the application of immunohistochemistry. Histopathology 2014;64(3):365-79.

52. Penman CL, Faulkner C, Lowis SP, et al. Current understanding of BRAF alterations in diagnosis, prognosis, and therapeutic targeting in pediatric low-grade gliomas. Front Oncol 2015;5:54.

53. Horbinski C. To BRAF or not to BRAF: is that even a question anymore? J Neuropathol Exp Neurol 2013;72(1):2-7.

54. EIF5 Gene - GeneCards - IF5 Protein - IF5 Antibody [Internet]. Available from: https://genecards. 
weizmann.ac.il/v3/cgi-bin/carddisp.pl?gene=PIK3 $\mathrm{R} 1 \&$ search $=$ ede0891f7268613a931729fe172fd2c0

55. PIK3CA Gene - GeneCards. PK3CA Protein / PK3CAAntibody [Internet]. Available from: https:// genecards.weizmann.ac.il/v3/cgi-bin/carddisp.pl?g ene $=$ PIK3CA\&search $=$ ede0891f7268613a931729f $\mathrm{e} 172 \mathrm{fd} 2 \mathrm{c} 0$

56. Carragher NO, Unciti-Broceta A, Cameron DA. Advancing cancer drug discovery towards more agile development of targeted combination therapies. Future Med Chem 2012;4(1):87-105.

57. PTEN Gene - GeneCards. PTEN Protein / PTEN Antibody [Internet]. Available from: http://www. genecards.org/cgi-bin/carddisp.pl?gene $=$ PTEN

58. Saha R, Chatterjee U, Mandal S, et al. Expression of phosphatase and tensin homolog, epidermal growth factor receptor, and Ki-67 in astrocytoma: A prospective study in a tertiary care hospital. Indian J Med Paediatr Oncol 2014;35(2):149.

59. Phillips HS, Kharbanda S, Chen R, et al. Molecular subclasses of high-grade glioma predict prognosis, delineate a pattern of disease progression, and resemble stages in neurogenesis. Cancer Cell 2006;9(3):157-73.

60. TP53 Gene - GeneCards. P53 Protein / P53 Antibody [Internet]. Available from: http:// www.genecards.org/cgi-bin/carddisp.pl?gene= TP53\&keywords=TP53

61. Gomez-Manzano C, Fueyo J, Kyritsis AP, et al. Characterization of p53 and p21 functional interactions in glioma cells en route to apoptosis. JNCI J Natl Cancer Inst 1997;89(14):1036-44.

62. CDKN1A Gene - GeneCards. CDN1A Protein / CDN1A Antibody CDKN1A Gene - GeneCards | CDN1A Protein | CDN1A Antibody [Internet]. Available from: https://genecards.weizmann.ac.il/ v3/cgi-bin/carddisp.pl?gene $=$ CDKN1A\&search $=b$ 10d1153e30b23e1591ee5fa04149f42

63. MDM2 Gene - GeneCards. MDM2 Protein / MDM2 Antibody [Internet]. Available from: http://www.genecards.org/cgi-bin/carddisp.pl? gene $=$ MDM $2 \&$ keywords $=$ MDM2

64. Costa B, Bendinelli S, Gabelloni P, et al. Human glioblastoma multiforme: $\mathrm{P} 53$ reactivation by a novel MDM2 inhibitor. PLoS One 2013;8(8):e72281.

65. Halatsch ME, Schmidt U, Unterberg A, et al. Uniform MDM2 overexpression in a panel of glioblastoma multiforme cell lines with divergent EGFR and p53 expression status. Anticancer Res 2006;26(6B):4191-4.

66. Riemenschneider MJ, Büschges R, Wolter M, et al. Amplification and overexpression of the MDM4 (MDMX) gene from 1q32 in a subset of malignant gliomas without TP53 mutation or MDM2 amplification. Cancer Res 1999;59(24):6091-6.
67. IDH1 Gene - GeneCards. IDHC Protein / IDHC Antibody [Internet]. Available from: http://www. genecards.org/cgi-bin/carddisp.pl?gene=IDH1

68. IDH2 Gene - GeneCards. IDHP Protein / IDHP Antibody [Internet]. Available from: https://genecards. weizmann.ac.il/v3/cgi-bin/carddisp.pl?gene=IDH2 \&search $=281 \mathrm{c} 3 \mathrm{deab} 424 \mathrm{c} 97785 \mathrm{a} 96 \mathrm{e} 0444 \mathrm{a} 0943 \mathrm{e}$

69. Vigneswaran K, Neill S, Hadjipanayis CG. Beyond the World Health Organization grading of infiltrating gliomas: advances in the molecular genetics of glioma classification. Ann Transl Med 2015;3(7):95.

70. Stancheva G, Goranova T, Laleva M, et al. IDH1/ IDH2 but not TP53 mutations predict prognosis in Bulgarian glioblastoma patients. Biomed Res Int 2014;2014:654727.

71. Cai J, Zhang C, Zhang W, et al. ATRX, IDH1-R132H and Ki-67 immunohistochemistry as a classification scheme for astrocytic tumors. Oncoscience 2016;3(7-8):258-265.

72. AKT3 Gene - GeneCards. AKT3 Protein / AKT3 Antibody [Internet]. Available from: http://www. genecards.org/cgi-bin/carddisp.pl?gene=AKT3

73. Joy A, Kapoor M, Georges J, et al. The role of AKT isoforms in glioblastoma: AKT3 delays tumor progression. J Neurooncol 2016;130(1):43-52.

74. Mure H, Matsuzaki K, Kitazato KT, et al. Akt2 and Akt3 play a pivotal role in malignant gliomas. Neuro Oncol 2010;12(3):221-32.

75. Kakkar A, Suri V, Jha P, et al. Loss of heterozygosity on chromosome $10 \mathrm{q}$ in glioblastomas, and its association with other genetic alterations and survival in Indian patients. Neurol India 2011;59(2):254-61.

76. Fujisawa H, Reis RM, Nakamura M, et al. Loss of heterozygosity on chromosome 10 is more extensive in primary (De Novo) than in secondary glioblastomas. Lab Investig 2000;80(1):65-72.

77. Ohgaki H, Kleihues P. Genetic pathways to primary and secondary glioblastoma. Am J Pathol 2007;170(5):1445-53.

78. Maier D, Comparone D, Taylor E, et al. New deletion in low-grade oligodendroglioma at the glioblastoma suppressor locus on chromosome 10q25-26. Oncogene 1997;15(8):997-1000.

79. Rasheed BK, McLendon RE, Friedman HS, et al. Chromosome 10 deletion mapping in human gliomas: a common deletion region in $10 \mathrm{q} 25$. Oncogene 1995;10(11):2243-6.

80. Hartmann C, Nümann A, Mueller W, et al. Fine mapping of chromosome $22 \mathrm{q}$ tumor suppressor gene candidate regions in astrocytomas. Int J Cancer 2004;108(6):839-44.

81. Purow B, Schiff D. Advances in the genetics of glioblastoma: are we reaching critical mass? Nat Rev Neurol 2009;5(8):419-26.

82. Zainuddin N, Jaafar H, Isa MN, et al. Loss of 
heterozygosity on chromosomes $10 \mathrm{q}, 9 \mathrm{p}, 17 \mathrm{p}$ and $13 \mathrm{q}$ in Malays with malignant glioma. Neurol Res 2004;26(1):88-92.

83. Nakamura M, Yang F, Fujisawa H, et al. Loss of heterozygosity on chromosome 19 in secondary glioblastomas. J Neuropathol Exp Neurol 2000;59(6):539-43.

84. Mariani L, Deiana G, Vassella E, et al. Loss of heterozygosity $1 \mathrm{p} 36$ and $19 \mathrm{q} 13$ is a prognostic factor for overall survival in patients with diffuse WHO grade 2 gliomas treated without chemotherapy. J Clin Oncol 2006;24(29):4758-63.

85. Vogazianou AP, Chan R, Bäcklund LM, et al. Distinct patterns of $1 p$ and $19 q$ alterations identify subtypes of human gliomas that have different prognoses. Neuro Oncol 2010;12(7):664-78.

86. Zhao J, Ma W, Zhao H. Loss of heterozygosity $1 \mathrm{p} / 19 \mathrm{q}$ and survival in glioma: A meta-analysis. Neuro Oncol 2014;16(1):103-12.

87. Yeung JT, Hamilton RL, Ohnishi K, et al. LOH in the HLA class I region at 6p21 is associated with shorter survival in newly diagnosed adult glioblastoma. Clin Cancer Res 2013;19(7):1816-26.

88. Daniel FI, Cherubini K, Yurgel LS, et al. The role of epigenetic transcription repression and DNA methyltransferases in cancer. Cancer 2011;117(4):677-87.

89. Kanwal R, Gupta S. Epigenetic modifications in cancer. Clin Genet 2012;81(4):303-11.

90. Nagarajan RP, Costello JF. Epigenetic mechanisms in glioblastoma multiforme. Semin Cancer Biol 2009;19(3):188-97.

91. Mathews LA, Crea F, Farrar WL. Epigenetic gene regulation in stem cells and correlation to cancer. Differentiation 2009;78(1):1-17.

92. Dupont C, Armant DR, Brenner CA. Epigenetics: Definition, mechanisms and clinical perspective. Semin Reprod Med 2009;27(5):351-7.

93. Kim JK, Samaranayake M, Pradhan S. Epigenetic mechanisms in mammals. Cell Mol Life Sci 2009;66(4):596-612.

94. Handy DE, Castro R, Loscalzo J. Epigenetic modifications: Basic mechanisms and role in cardiovascular disease. Circulation 2011;123(19):2145-56.

95. Kim KH, Choi JS, Kim IJ, et al. Promoter hypomethylation and reactivation of MAGE-A1 and MAGEA3 genes in colorectal cancer cells liners and cancer tissues. World J Gastroenterol 2006;12(35):5651-7.

96. Xiao J, Chen HS, Fei R, et al. Expression of MAGEA 1 mRNA is associated with gene hypomethylation in hepatocarcinoma cell lines. J Gastroenterol 2005;40(7):716-21.

97. Phuphanich S, Wheeler CJ, Rudnick JD, et al. Phase I trial of a multi-epitope-pulsed dendritic cell vaccine for patients with newly diagnosed glioblastoma. Cancer Immunol Immunother 2013;62(1):125-35.
98. Rajendran G, Shanmuganandam K, Bendre A, et al. Epigenetic regulation of DNA methyltransferases: DNMT1 and DNMT3B in gliomas. J Neurooncol 2011;104(2):483-94.

99. Mao H, LeBrun DG, Yang J, et al. Deregulated signaling pathways in glioblastoma multiforme: molecular mechanisms and therapeutic targets. Cancer Invest 2012;30(1):48-56.

100.Jesionek-Kupnicka D, Szybka M, Malachowska B, et al. TP53 promoter methylation in primary glioblastoma: relationship with TP53 mRNA and protein expression and mutation status. DNA Cell Biol 2014;33(4):217-26.

101.Burgess R, Jenkins R, Zhang Z. Epigenetic changes in gliomas. Cancer Biol Ther 2008;7(9):1326-34.

102. Waha A, Waha A, Koch A, et al. Epigenetic silencing of the HIC-1 gene in human medulloblastomas. J Neuropathol Exp Neurol 2003;62(11):1192-201.

103.Martínez R. Beyond genetics in glioma pathways: the ever-increasing crosstalk between epigenomic and genomic events. J Signal Transduct 2012:1-9.

104.Guo Y, Su ZY, Kong ANT. Current perspectives on epigenetic modifications by dietary chemopreventive and herbal phytochemicals. Curr Pharmacol Reports 2015;1(4):245-57.

105.Sturm D, Bender S, Jones DTW, et al. Paediatric and adult glioblastoma: multiform (epi)genomic culprits emerge. Nat Rev Cancer 2014;14(2):92-107.

106.Darefsky AS, King JT, Dubrow R. Adult glioblastoma multiforme survival in the temozolomide era: A population-based analysis of surveillance, epidemiology, and end results registries. Cancer 2012;118(8):2163-72.

107.Zhang J, Yang JH, Quan J, et al. Identification of MGMT promoter methylation sites correlating with gene expression and IDH1 mutation in gliomas. Tumor Biol 2016;37(10):13571-9.

108. Chernov AV, Strongin AY. Epigenetic regulation of matrix metalloproteinases and their collagen substrates in cancer. Biomol Concepts 2011;2(3):135-47.

109. Sarkar SH, Ahmad A, Mittal S. The therapeutic role of microRNAs in human gliomas. In: MicroRNA Targeted Cancer Therapy. Cham: Springer International Publishing; 2014. p. 1-27.

110.Sun L, Yan W, Wang Y, et al. MicroRNA-10b induces glioma cell invasion by modulating MMP14 and UPAR expression via HOXD10. Brain Res 2011;1389:9-18.

111.Xia H, Qi Y, Ng SS, et al. MicroRNA-15b regulates cell cycle progression by targeting cyclins in glioma cells. Biochem Biophys Res Commun 2009;380(2):205-10.

112.Ernst A, Campos B, Meier J, et al. De-repression of CTGF via the miR-17-92 cluster upon differentiation 
of human glioblastoma spheroid cultures. Oncogene 2010;29(23):3411-22.

113.Zhou X, Zhang J, Jia Q, et al. Reduction of miR-21 induces glioma cell apoptosis via activating caspase 9 and 3. Oncol Rep 2010;24(1):195-201.

114.Li S-J, Zhou J, Zhang L, et al. The effect of miR-21 on SWOZ2 glioma cells and its biological mechanism. J BUON 2016;22(2):468-73.

115.Becker Buscaglia LE, Li Y. Apoptosis and the target genes of miR-21. Chin J Cancer 2011;30(6):371-80.

116.Lian S, Shi R, Bai T, et al. Anti-miRNA-23a oligonucleotide suppresses glioma cells growth by targeting apoptotic protease activating factor-1. Curr Pharm Des 2013;19(35):6382-9.

117.Jiang L, Wang C, Lei F, et al. MiR-93 promotes cell proliferation in gliomas through activation of PI3K/Akt signaling pathway. Oncotarget 2015;6(10):8286-99.

118.Fang L, Deng Z, Shatseva T, et al. MicroRNA miR93 promotes tumor growth and angiogenesis by targeting integrin- $\beta 8$. Oncogene 2011;30(7):806-21.

119.Zhang C, Zhang J, Hao J, et al. High level of miR$221 / 222$ confers increased cell invasion and poor prognosis in glioma. J Transl Med 2012;10(1):119.

120.Cai G, Qiao S, Chen K. Suppression of miR-221 inhibits glioma cells proliferation and invasion via targeting SEMA3B. Biol Res 2015;48(1):37.

121.Shu M, Zheng X, Wu S, et al. Targeting oncogenic miR-335 inhibits growth and invasion of malignant astrocytoma cells. Mol Cancer 2011;10(1):59.

122.Tang H, Wang Z, Liu Q, et al. Disturbing miR-182 and -381 inhibits BRD7 transcription and Glioma growth by directly targeting LRRC4. PLoS One 2014;9(1):e84146.

123.Krock BL, Skuli N, Simon MC. Hypoxia-induced angiogenesis: good and evil. Genes Cancer 2011;2(12):1117-33.

124.Qin Q, Furong W, Baosheng L. Multiple functions of hypoxia-regulated miR-210 in cancer. J Exp Clin Cancer Res 2014;33:50.

125.Wu DG, Wang YY, Fan LG, et al. MicroRNA-7 regulates glioblastoma cell invasion via targeting focal adhesion kinase expression. Chin Med J (Engl) 2011;124(17):2616-21.

126.Lu ZJ, Liu SY, Yao YQ, et al. The effect of miR-7 on behavior and global protein expression in glioma cell lines. Electrophoresis 2011;32(24):3612-20.

127.Kefas B, Godlewski J, Comeau L, et al. MicroRNA-7 inhibits the epidermal growth factor receptor and the akt pathway and is down-regulated in glioblastoma. Cancer Res 2008;68(10):3566-72.

128.Suh S-S, Yoo JY, Nuovo GJ, et al. MicroRNAs/TP53 feedback circuitry in glioblastoma multiforme. Proc Natl Acad Sci 2012;109(14):5316-21.

129.Silber J, Jacobsen A, Ozawa T, et al. MiR-34a repression in proneural malignant gliomas upregulates expression of its target PDGFRA and promotes tumorigenesis. Reis RM, editor. PLoS One 2012;7(3):e33844.

130.Luan S, Sun L, Huang F. MicroRNA-34a: A novel tumor suppressor in p53-mutant glioma cell line U251. Arch Med Res 2010;41(2):67-74.

131. Guessous F, Zhang Y, Kofman A, et al. MicroRNA$34 \mathrm{a}$ is tumor suppressive in brain tumors and glioma stem cells. Cell Cycle 2010;9(6):1031-6.

132. Yunqing L, Guessous F, Ying Z, et al. MicroRNA34 a inhibits glioblastoma growth by targeting multiple oncogenes. Cancer Res 2009;69(19):7569-76.

133. Vo DT, Qiao M, Smith AD, et al. The oncogenic RNA-binding protein Musashi1 is regulated by tumor suppressor miRNAs. RNA Biol 2011;8(5):817-28.

134.Smits M, Nilsson J, Mir SE, et al. MiR-101 is down-regulated in glioblastoma resulting in EZH2induced proliferation, migration, and angiogenesis. Oncotarget 2010;1(8):710-20.

135.Geekiyanage H, Galanis E. MiR-31 and miR-128 regulates poliovirus receptor-related 4 mediated measles virus infectivity in tumors. Mol Oncol 2016;10(9):1387-403.

136.Shang C, Hong Y, Guo Y, et al. MiR-128 regulates the apoptosis and proliferation of glioma cells by targeting RhoE. Oncol Lett 2015;11(1):904-8.

137.Papagiannakopoulos T, Friedmann-Morvinski D, Neveu P, et al. Pro-neural miR-128 is a glioma tumor suppressor that targets mitogenic kinases. Oncogene 2012;31(15):1884-95.

138.Shan Z-N, Tian R, Zhang M, et al. MiR128-1 inhibits the growth of glioblastoma multiforme and glioma stem-like cells via targeting BMI1 and E2F3. Oncotarget 2016;7(48):78813-26.

139. Wuchty S, Arjona D, Li A, et al. Prediction of associations between microRNAs and gene expression in glioma biology. PLoS One 2011;6(2):e14681.

140.Anand S, Majeti BK, Acevedo LM, et al. MicroRNA-132-mediated loss of p120RasGAP activates the endothelium to facilitate pathological angiogenesis. Nat Med 2010;16(8):909-14.

141.Chen S, Wang Y, Ni C, et al. HLF/miR-132/TTK axis regulates cell proliferation, metastasis and radiosensitivity of glioma cells. Biomed Pharmacother 2016;83:898-904.

142.Silber J, Lim DA, Petritsch C, et al. MiR-124 and miR-137 inhibit proliferation of glioblastoma multiforme cells and induce differentiation of brain tumor stem cells. BMC Med 2008;6(1):14.

143. Wang S, Lu S, Geng S, et al. Expression and clinical significance of microRNA-326 in human glioma miR-326 expression in glioma. Med Oncol 2013;30(1):373.

144.Kefas B, Comeau L, Erdle N, et al. Pyruvate 
kinase M2 is a target of the tumorsuppressive microRNA-326 and regulates the survival of glioma cells. Neuro Oncol 2010;12(11):1102-12.

145.Kefas B, Comeau L, Floyd DH, et al. The neuronal microRNA miR-326 acts in a feedback loop with notch and has therapeutic potential against brain tumors. J Neurosci 2009;29(48):15161-8.

146. Vander Heiden MG, Cantley LC, Thompson CB. Understanding the Warburg effect: the metabolic requirements of cell proliferation. Science 2009;324(5930):1029-33.

147.Ponisovskiy MR. Warburg effect mechanism as the target for theoretical substantiation of a new potential cancer treatment. Crit Rev Eukaryot Gene Expr 2011;21(1):13-28.

148.Wang L, Shi M, Hou S, et al. MiR-483-5p suppresses the proliferation of glioma cells via directly targeting ERK1. FEBS Lett 2012;586(9):1312-7.

149.Xu B, Zhang YW, Tong XH, et al. Characterization of microRNA profile in human cumulus granulosa cells: identification of microRNAs that regulate Notch signaling and are associated with PCOS. Mol Cell Endocrinol 2015;404:26-36.

150.Li X, Liu Y, Granberg KJ, et al. Two mature products of MIR-491 coordinate to suppress key cancer hallmarks in glioblastoma. Oncogene 2015;34(13):1619-28.

151.Yan W, Zhang W, Sun L, et al. Identification of MMP-9 specific microRNA expression profile as potential targets of anti-invasion therapy in glioblastoma multiforme. Brain Res 2011;1411:108-15.

152. Cui SY, Wang R, Chen LB. MicroRNA-145: A potent tumour suppressor that regulates multiple cellular pathways. J Cell Mol Med 2014;18(10):1913-26.

153. Shi L, Wang Z, Sun G, et al. MiR-145 inhibits migration and invasion of glioma stem cells by targeting ABCG2. NeuroMolecular Med 2014;16(2):517-28.

154.Lee HK, Bier A, Cazacu S, et al. MicroRNA-145 is downregulated in glial tumors and regulates glioma cell migration by targeting connective tissue growth factor. PLoS One 2013;8(2):e54652.

155.Lee SJ, Kim SJ, Seo HH, et al. Over-expression of miR-145 enhances the effectiveness of HSVtk gene therapy for malignant glioma. Cancer Lett 2012;320(1):72-80.
156.De Angelis LM, Mellinghoff IK. Virchow 2011 or how to $\mathrm{ID}(\mathrm{H})$ human glioblastoma. J Clin Oncol 2011;29(34):4473-4.

157.Aguilar LK, Arvizu M, Aguilar-Cordova E, et al. The spectrum of vaccine therapies for patients with glioblastoma multiforme. Curr Treat Options Oncol 2012;13(4):437-50.

158. Saha D, Martuza RL, Curry WT. Viral oncolysis of glioblastoma. In: Neurotropic Viral Infections: Volume 2: Neurotropic Retroviruses, DNA Viruses, Immunity and Transmission. Cham: Springer International Publishing; 2016; p. 481-517.

159.Ning J, Wakimoto H, Peters C, et al. Rad51 degradation: role in oncolytic virus -- poly(ADP-Ribose) polymerase inhibitor combination therapy in glioblastoma. JNCI J Natl Cancer Inst 2017;109(3):1-13.

160.Schijns VEJC. A personalized immunotherapeutic vaccine (Gliovac Or ERC1671) against recurrent glioblastoma multiforme (GBM). Brain Disord Ther 2015; S2.

161.Santiago-Dieppa DR, Steinberg J, Gonda D, et al. Extracellular vesicles as a platform for "liquid biopsy" in glioblastoma patients. Expert Rev Mol Diagn 2014;14(7):819-25.

162.Karachaliou N, Mayo-de-las-casas C, Molina-vila MA, et al. Real-time liquid biopsies become a reality in cancer treatment. Ann Transl Med 2015;3(3):2-4.

163.Best MG, Sol N, Zij1 S, et al. Liquid biopsies in patients with diffuse glioma. Acta Neuropathol 2015;129(6):849-65.

164.Jung CS, Foerch C, Schänzer A, et al. Serum GFAP is a diagnostic marker for glioblastoma multiforme. Brain 2007;130(12):3336-41.

165. Tichy J, Spechtmeyer S, Mittelbronn M, et al. Prospective evaluation of serum glial fibrillary acidic protein (GFAP) as a diagnostic marker for glioblastoma. J Neurooncol 2015;126(2):361-9.

166.Dall'Oglio S, D'Amico A, Pioli F, et al. Doseintensity temozolomide after concurrent chemoradiotherapy in operated high-grade gliomas. J Neurooncol 2008;90(3):315-9.

167.Krex D, Klink B, Hartmann C, et al. Long-term survival with glioblastoma multiforme. Brain 2007;130(10): 2596-606. 


\title{
Относительно понятий и анамнеза мультиформной глиобластомы - морфология, генетика и эпигенетика
}

\author{
Георги Ст. Стоянов, Деян Д. Дженков
}

Кафедра общей и клинической патологии, судебной медицины и деонтология, Медицинский университет - Варна „Проф. Д-р Параскев Стоянов", Варна, Болгария

\begin{abstract}
Адрес для корреспонденции: Георги Ст. Стоянов, Кафедра общей и клинической патологии, судебной медицины и деонтологии, Медицинский университет - Варна "Проф. Д-р Параскев Стоянов", ул. „Христо Смирненски" 1, 9002, Варна, Болгария E-mail: georgi.geesh@gmail.com Tel: +359889922240
\end{abstract}

Дата получения: 17 апреля 2017

Дата приемки: 20 июля 2017 Дата онлайн публикации: 23 июля 2017

Дата публикации: 30 марта 2018

Ключевые слова: мультиформная глиобластома, центральная нервная система, онкология, историческое обозрение понятий

Образец цитирования: Stoyanov GS, Dzhenkov DL. On the concepts and history of glioblastoma multiforme - morphology, genetics and epigenetics. Folia Med (Plovdiv) 2018;60(1):48-66.

doi: 10.1515/folmed-2017-0069
Мультиформная глиобластома (МГБ) является злокачественной опухолью IV степени согласно классификации Всемирной организации здравоохранения астроцитарной дифференциации. Так как она является одним из наиболее часто диагностированных онкологических проявлений центральной нервной системы, существует большое количество докладов, рассматривающих описание и развитие идей, связанных с данным типом опухолей.

Первый зарегистрированный случай глиомы представлен в Британском научном докладе Бернсом в 1800 году и в 1804 году - Абернети, а первое подробное гистоморфологическое описание представлено в 1865 году Рудольфом Вирховым. В 1926 году Персиваль Бэйли и Харви Кушинг создают основу современной классификации глиомов. Между 1934 и 1941 годами наиболее продуктивным учёным в области исследования глиом является Ганс-Йоаким Шерер, который устанавливает некоторые из клинико-морфологических аспектов МГБ. После появления молекулярных и генетических исследований установлено исключительное многообразие МГБ, при котором разные генотипы являются носителями одних и тех же гистоморфологических и ИГХ моделей, а также и некоторые аспекты глиомагенеза. Развитие МГБ начинается или с активации определённого типа мутации в МГБ стволовой клетке - первичная МГБ, или с медленного накапливания отдельных мутаций, без наличия определённой мутации, активирующей процесс - вторичная МГБ.

Знания в области МГБ тесным образом связаны с общими медицинскими знаниями о ЦНС, так как эти злокачественные образования описаны более двухсот лет назад. За это время произошёл большой скачок в науке как в области знаний о ЦНС, так и в области общих знаний в медицине. 